\title{
The habitat and status of Spix's Macaw Cyanopsitta spixii
}

\author{
A. T. JUNIPER and C. YAMASHITA
}

\section{Summary}

Spix's Macaw Cyanopsitta spixii has always been a very poorly known species from the arid interior of north-east Brazil. Previous views that its habitat is buriti palm swamp appear mistaken, as the most recent field observations and the testimony of local people suggest that Tabebuia caraiba gallery woodland along seasonal creeks is a critical habitat component. Owing to widespread destruction of such woodland, during a survey in June/July 1990 only three good patches were found, all failing to regenerate; one held a single bird, and another held birds up to last year.

A Ararinha-azul Cyanopsitta spixii sempre foi uma espécie pouco conhecida no interior árido do nordeste do Brasil. Opiniōes anteriores que o seu habitat é buritizais parecem erradas porque as observações de campo mais recentes e o testimônio dos habitantes locais sugestem que matas de Tabebuia caraiba ao longo de riachos estacionais são um crítico componente do habitat. Devido à destruição extensa deste tipo de mata, durante um levantamento em junho/julho 1990 somente tres áreas boas foram achadas, todas sem regeneração; uma abrigava um único pássaro, e uma outra abrigava pássaros até o ano passado.

\section{Introduction}

Spix's Macaw Cyanopsitta spixii occupies a monotypic genus and is one of the least known of Neotropical parrots. Indeed, since the first specimen was collected by Spix in the dry north-east of Brazil around 1819, the species has been known from only sporadic sightings from the same general area, a few captive birds and a handful of museum specimens.

This dearth of distributional knowledge of the species has hampered attempts to identify its preferred habitat and thereby to determine more clearly the reasons for its chronic rarity. Spix found it at Juazeiro in northern Bahia, and Kaempfer also saw it there in 1927; the habitat of the area was then described as "low underbrush and ... stretches of open campo country covered with grass" (Naumburg 1928). Between these two sightings was one by Reiser in 1903, in the region of Parnaguá, in the extreme south of Piauí (Pinto 1938); this area is a transition zone between the cerrado and the more arid caatinga vegetation of the east, and is characterised by deciduous forests which are quite distinct from the scrubby caatinga (pers. obs.).

In more recent years the view has developed that Spix's Macaw is dependent on palm trees. Meyer de Schauensee (1971) cited palm groves as its habitat, and Ridgely (1981) and Sick (1985) both indicated that the palms in question were 
buriti Mauritia flexuosa. The latter reports seeing Cyanopsitta in 1974 at Formosa do Rio Preto - a locality in north-western Bahia over $600 \mathrm{~km}$ to the west of the type-locality - where two parties of three and four birds respectively were seen flying over buriti palms. Ridgely (1981) added that the species also foraged into adjacent deciduous woodland and caatinga, although in our experience the woodlands that surround the damp areas containing $M$. flexuosa tend to be evergreen cerrado formations, particularly in north-western Bahia.

Ridgely (1981) and Silva (1989) both give the distribution of Spix's Macaw as "southern Piauí, extreme southern Maranhão, north-eastern Goiás and northwestern Bahia", while Forshaw and Cooper (1989) provide a slightly modified version of this which substitutes "extreme south-western Pernambuco" for anywhere in Goiás. These delimitations are based on the above records supplemented by various reports and assertions in unpublished documentation of the species. Buriti palm swamps occur throughout this massive area, and this, combined with the remoteness of the region and the lack of clear evidence at the time for any decline, led Ridgely (1981) to consider it rare and few in number, but not critically at risk.

Only with Roth's rediscovery of the species in 1986 came the perception that seasonal watercourses fringed with Tabebuia caraiba trees were a particularly striking feature of the bird's habitat, which otherwise consisted of caatinga with a predominance of Euphorbiaceae. Even so, it was not clear how important these caraiba (or craibeira) trees might be to the species. During his fieldwork, which extended sporadically over four years from 1985 to 1988 , Roth attempted to follow up as many reports as possible, whether from the few published sources above or from local informants, and it was obviously extremely difficult to distinguish degrees of reliability in all this material. Nevertheless Silva (1989), whose account very largely depends on Roth's work, mentions that "where craibeiras have been felled, as in the Pernambuco side of the São Francisco River, the species has disappeared".

Having exhausted many different leads, Roth (1990, and in unpublished reports) believed that the population (three birds) he found in 1985 at Curaça was the last remaining, and that it was also the first found, being close enough to Juazeiro to have been the very same from which Spix had taken the type. He also believed that this population became extinct (through illegal trapping) during his period of study. However, reports of birds from various parts of the stated range, including rumours of young being sold illegally from nests in the wild, formed the basis of a proposal to the International Council for Bird Preservation (ICBP) from Luiz Claudio Marigo and Francisco Pontual for a further survey to determine whether another population might still exist. The general conclusions and recommendations from this work have been published elsewhere (Juniper and Yamashita 1990), but here we report in detail on the ecological aspects of the survey.

\section{Methods}

During June and July 1990, a search for wild Spix's Macaws was carried out over a large portion of the species's range as suggested by previous published sources and, in particular, by certain recent unconfirmed reports. The expedition 
targeted particular areas and - equipped with two four-wheel-drive vehicles visited the following localities: (I) the Chapada das Mangabeiras (reports of apparent Spix's Macaws in this portion of southern Piauí were supplied by Brazilian ornithologists who were familiar with the region; these were investigated with a direct ground search); (2) areas in southern Piauí and northern Bahia on the north side of the Rio São Francisco not covered by Roth in his searches during 1985-1988; and (3) the sites from which birds were reported by Sick (1985), Reiser (in Pinto 1938) and Roth (1990).

The actual search methods relied primarily on interviews with local people, particularly bird-trappers and farmers who had a good knowledge of their local avifauna, and on direct searches with telescopes and binoculars in areas where good information suggested a possibility of surviving Spix's Macaws. In the region of northern Bahia where a single bird was located (in a patch of $T$. caraiba gallery woodland along the Melância creek near to the Rio São Francisco actually the same locality as that found by Roth), a search for other areas of similar habitat was conducted in order to improve the chances of finding further birds.

The following methods were used in this search:

(1) A transect crossing all of the major seasonal creeks (on which the T. caraiba woodlands evidently rely) was travelled for over $200 \mathrm{~km}$ between Juazeiro and Abaré on the southern shores of the Rio São Francisco. Regular searches using telescopes and binoculars were made across the flat landscape so that a belt transect of around $4 \mathrm{~km}$ width was effectively surveyed.

(2) Local people, including farmers and an agricultural land-use planner with access to a set of aerial photographs, were interviewed.

(3) Wider searches using four-wheel-drive vehicles were conducted south of the Rio São Francisco, particularly between Curaçá, Icozeira and Abaré.

The structure of the $T$. caraiba woodlands was quantified through the gathering of data on the height of mature trees, their diameter at breast height (DBH), distance from the nearest seasonal watercourse and the proportion of standing dead wood. In addition, measurements were collected on sapling and seedling density, and the density of holes suitable for Spix's Macaw nest-sites (holes in excess of $12 \mathrm{~cm}$ diameter that had been "finished" by psittacines) was assessed. Notes were taken on the nature of the substrate where the woodlands grew and on the size and morphology of the channels. This information was collected from $100 \mathrm{~m}$ sections of creek in 10 locations. In all locations, there was good evidence for the current, recent or historical presence of Spix's Macaw.

\section{Results}

The population and distribution of Spix's Macaw

The only locality where conclusive evidence for the continuing existence of Spix's Macaw could be found was in the T. caraiba woodlands near to Curaçá in northern Bahia. Indications from other areas were found to be either erroneous or unsubstantiated. However, a locality for Cyanopsitta that was previously unknown to ornithologists was found. Of the three remaining patches of $T$. caraiba gallery woodland that could be identified, only one (in Riacho da 


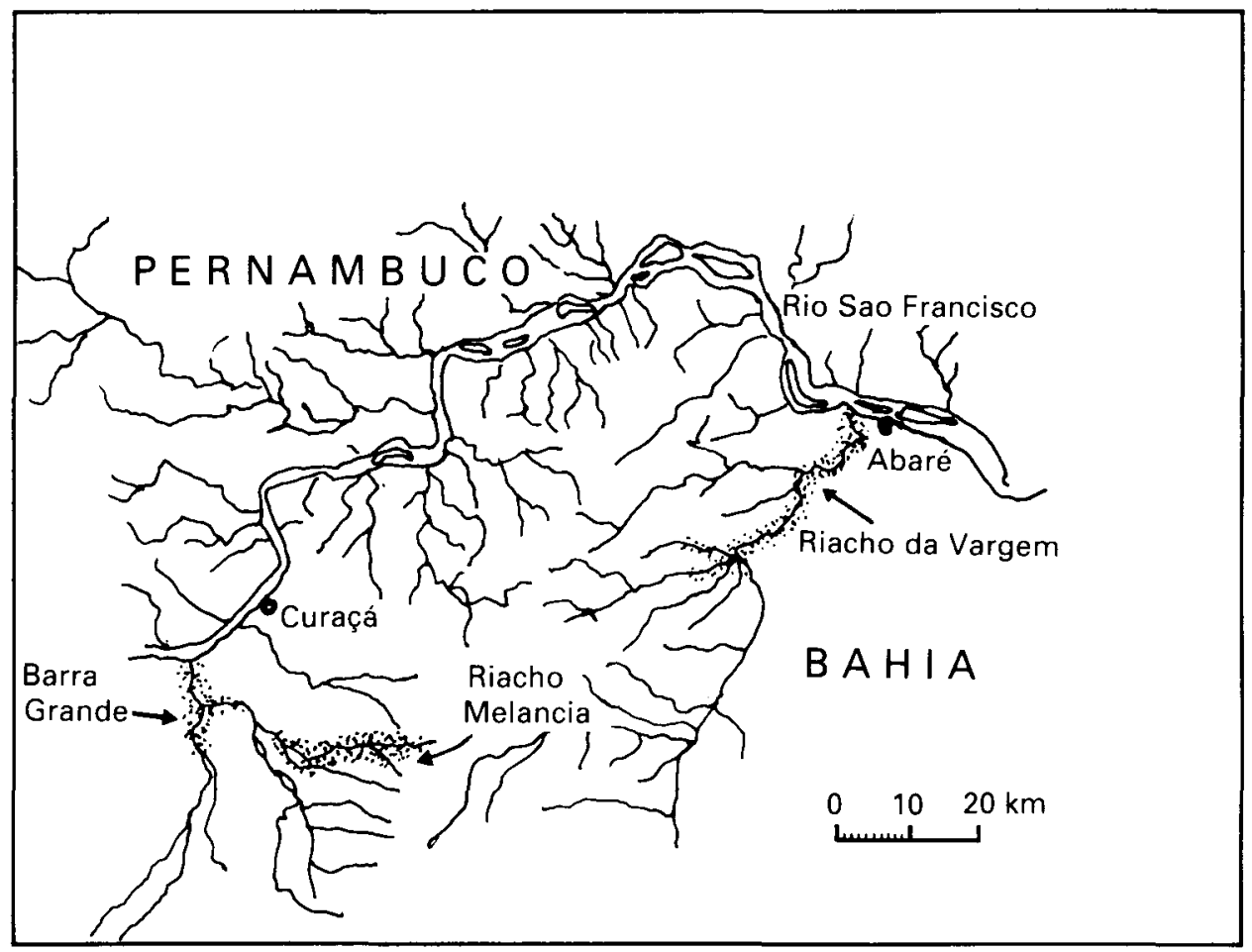

Figure 1. Approximate extent of remaining Tabebuia gallery woodlands (shown as spotted areas), the preferred habitat of Cyanopsitta.

Vargem, see Figure 1) had not previously been examined by ornithologists searching for Cyanopsitta. In this locality, the authors found conclusive evidence for the recent occurrence of Cyanopsitta. Local people were able to give very accurate descriptions of Cyanopsitta and its habits, and reported that it had occurred there within the last year. However, they thought that the last individuals had been taken by trappers. Birds taken from this hitherto unknown locality may account for the young Cyanopsitta reported in trade in 1987 when breeding failure was reported at the only known nest in the Melancia creek during the previous breeding season (Thomsen and Munn 1988).

\section{The habitat of Spix's Macaw}

The evidence gathered revealed the (former) presence of wild Spix's Macaws only in remnant patches of $T$. caraiba woodlands. Our observations over a oneweek period of July 1990 consistently found the single remaining wild bird in the vicinity of the Melância creek where $T$. caraiba specimens grew. The dead crowns of these trees were strongly favoured and the bird showed a preference for particular perches. These observations and the discovery of a new locality in very similar habitat suggest that nest-site availability was an important habitat feature for Cyanopsitta.

Although no conclusive evidence could be gathered to confirm such a prefer- 
ence, a strong positive correlation was found to exist between hole density and the amount of standing dead wood $(r=0.818, P<0.02)$. We found indications that the areas where both variables showed high values were the preferred areas for Cyanopsitta. The available information indicates that these coincided with areas in Table 1 with the highest number of potential nest holes (sample nos. 2, 3 and 7 in Table 1 ).

\section{The distribution of Tabebuia caraiba woodlands}

Despite the presence of a dense drainage network, $T$. caraiba currently forms gallery woods along only three seasonal watercourses within the entire region to the south of the São Francisco between Abaré and Juazeiro. The trees are fairly evenly distributed and occur at an average density of 10.2 mature specimens per $100 \mathrm{~m}$ (see Table 1 ). Although surrounded by structurally and floristically distinct caatinga vegetation, the gallery woods seem to be related to the caatinga region and $T$. caraiba is not known to occur elsewhere in a comparable formation. Although there are many creeks on both the right and left banks of the Rio São Francisco in north-eastern Bahia and southern Pernambuco, only very few support $T$. caraiba gallery woods.

The information collected indicated that two factors may be important determinants of the distribution of $T$. caraiba woodland. First, the presence of seasonally inundated watercourses above a certain size appeared crucial. Mature specimens of $T$. caraiba were only found in the vicinity of watercourses in excess of $8 \mathrm{~m}$ width. In ten $100 \mathrm{~m}$ sections of creek, it was found that the maximum average distance of trees from the nearest channel was only $17.6 \mathrm{~m}$ (see Table 1 ). In one section, all trees were in either the bank or the stream bed (section 7 of Table 1). In addition, those trees which did not occur in the watercourse or its bank were found in areas which were seasonally flooded.

Second, fine alluvial deposits were present. All T. caraiba woodland was recorded in the middle and lower levels of the creek system. The narrower and rockier upper reaches of the creeks were found to have no $T$. caraiba and it is perhaps absent here due to unfavourable regeneration conditions. Although regeneration of $T$. caraiba was generally found to be very poor, all seedlings and saplings were found in moist conditions and had germinated on fine sediments. Most were found either in the base of the larger creeks or in their banks.

It is not clear how extensive the conditions are for the formation of $T$. caraiba gallery woods in the region, but it is clear that only three small patches currently remain: one in Barra Grande (no birds present, but an old man from Curaçá reported shooting them for food many years before), a patch in Riacho Melância (where the last wild birds occurred) and a third in Riacho da Vargem (where we recorded a new locality for Cyanopsitta) (see Figure 1).

\section{Size-class structure of Tabebuia caraiba specimens and habitat degradation}

Our survey of $T$. caraiba woodland found that this habitat is not regenerating. An examination of the size-class structure of $T$. caraiba trees (see Table 2) shows that the population of this large tree in Barra Grande, Riacho da Vargem and Riacho Melância is dominated by a preponderance of very old specimens. 


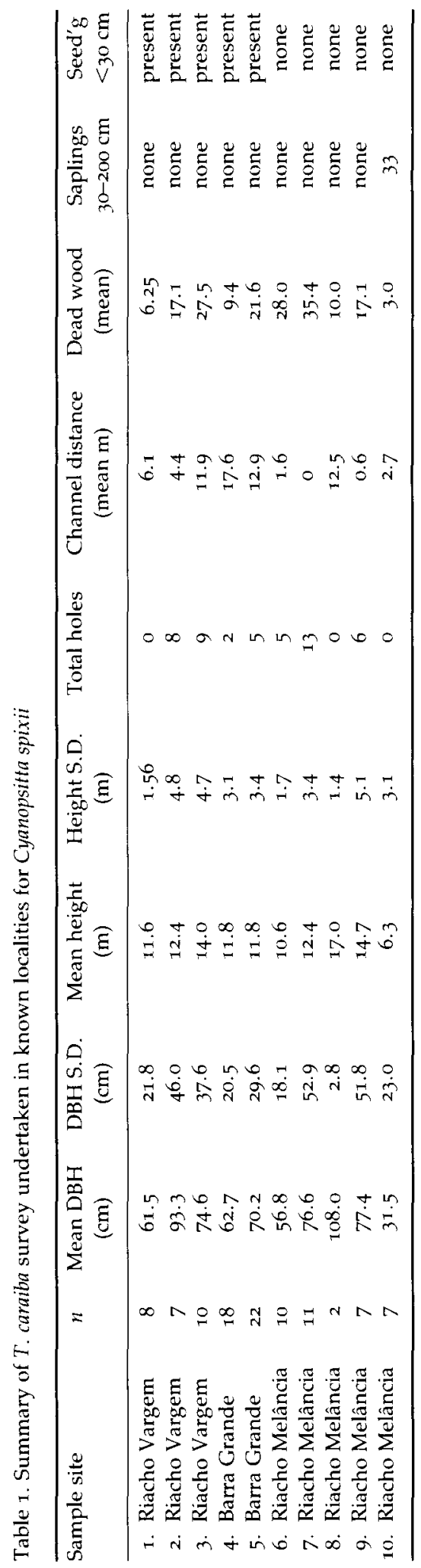


Table 2. Size-class structure of $T$. caraiba specimens over $30 \mathrm{~cm}$ height

\begin{tabular}{ccccccccc}
\hline $\begin{array}{c}\text { Saplings } \\
30-200 \mathrm{~cm} \text { high }\end{array}$ & $\begin{array}{c}\text { DBH } \\
10-20 \mathrm{~cm}\end{array}$ & $\begin{array}{c}\text { DBH } \\
21-40 \mathrm{~cm}\end{array}$ & $\begin{array}{c}\text { DBH } \\
41-60 \mathrm{~cm}\end{array}$ & $\begin{array}{c}\text { DBH } \\
61-80 \mathrm{~cm}\end{array}$ & $\begin{array}{c}\text { DBH } \\
81-100 \mathrm{~cm}\end{array}$ & $\begin{array}{c}\text { DBH } \\
>100 \mathrm{~cm}\end{array}$ & TOT \\
\hline$n$ & 33 & 2 & 23 & 23 & 20 & 19 & 14 & 134 \\
$\% n$ & 24.6 & 1.5 & 17.2 & 17.2 & 14.9 & 14.1 & 10.4 & 100 \\
\hline
\end{tabular}

Table 2 shows that only 1.5 per cent of specimens were in the $10-20 \mathrm{~cm} \mathrm{DBH}$ class and saplings between $30-200 \mathrm{~cm}$ in height were found in only one of the ten samples (see Table 1 ). Goats, sheep and cattle had been excluded from this sample where saplings were discovered, indicating clearly that excessive grazing pressure has led to poor regeneration of $T$. caraiba in the other samples. Furthermore, although several samples (particularly in Barra Grande and Riacho Vargem) were found with seedlings under $30 \mathrm{~cm}$ in height, most were seriously nibbled and would probably not survive the dry season.

\section{Discussion}

The evidence presented strongly suggests that, in historical times at least, Cyanopsitta has only occurred on the south bank of the Rio São Francisco in the area of the type-locality near to Curaçá in north-eastern Bahia, north-eastern Brazil. The published records from further west are very difficult to explain but conceivably stem from either escaped captive birds or more likely the misidentification of another species such as Red-bellied Macaw Ara manilata. It would appear most unlikely that Cyanopsitta undertook lengthy seasonal movements, especially since most field observations and the testimony of local people suggest extreme site-faithfulness.

The fact that Cyanopsitta has been held in collections for the last century or so may be one reason for the confusion concerning the range of this species. Trappers may provide poor-quality information to protect their supply, and dealers may possess second-hand information which becomes vaguer as the birds are passed on. Claims for the origins of captive specimens may rely on this kind of second- and third-hand hearsay and hence rarely relate to direct observation in the field by experienced observers.

If, as is suggested by earlier published accounts, Spix's Macaw is able to tolerate a wide range of vegetation-types, we would expect the information from other regions to be of much better quality. Only one psittacine species is regularly encountered in caatinga, cerrado and the deciduous forests of the region, namely Blue-fronted Amazon Amazona aestiva. This is a very common species and is the most abundant large parrot in many of the seasonal woodlands over a large portion of South America (Forshaw and Cooper 1989). Although the smaller Cactus Parakeet Aratinga cactorum and Peach-fronted Parakeet $A$. aurea may be found in regions characterised by both caatinga and cerrado, they tend to be associated with the patches of grassland that are a common feature of both formations rather than being reliant on the distinctive woodlands. If Cyanopsitta were indeed a "generalist", it would be expected that the species would be more familiar. 
Considering the failure of recent field searches to find evidence for the occurrence of Cyanopsitta in other habitats or regions, it is strongly suggested that it now only occurs (and has probably only ever occurred in historical times) in the $T$. caraiba gallery woods in the caatinga zone of northern Bahia. During the field search for Cyanopsitta in the areas to the west of the type-locality, we found many people with a good knowledge of their local avifauna yet, although the area searched is fairly evenly settled, it was only in the region of Curaçá, Abaré and Icozeira that individuals familiar with Cyanopsitta could be located. If this bird does occur in the western portion of its previously supposed range, it would appear most unlikely that no one knew of it.

Since the corridor of the Rio São Francisco in north-eastern Brazil has been settled for over 300 years, and considering that pastoralism has been the major land-use, it can be assumed that the extent of $T$. caraiba woodland is far less than before the colonisation of Brazil. Indeed, the very poor rate of regeneration is good reason to believe that the remaining woods are a tiny fraction of their former extent. If this is true, then it would explain the evident rarity of Cyanopsitta ever since the time of its discovery, and account for its particular vulnerability to trapping. In addition, our conversations with local farmers indicated that $T$. caraiba grows in places most preferred for the growing of subsistence crops such as maize. These areas are also where pasture lasts longest into the dry season. This has led to the siting of most human habitation in the creeks, which in turn has posed additional pressure through the collection of fuelwood.

All this leads us to conclude that in recent times Spix's Macaw has only occurred on the banks of the Rio São Francisco in north-eastern Bahia, northeastern Brazil. It was confined to the areas where $T$. caraiba forms gallery woodlands; the limited extent of this habitat-type explains its original scarcity and susceptibility to trapping for the black market in live birds. Indeed, since only a single individual is thought to remain, we conclude that trapping for the live trade has led to the virtual extinction of Cyanopsitta in nature.

\section{Acknowledgements}

We would like to highlight the outstanding contribution to the field search for Spix's Macaw made by Luiz Claudio Marigo, Francisco Pontual and Roberto Otoch. We wish to thank the International Council for Bird Preservation and the World Parrot Trust for their financial support, and A.T.J. acknowledges the support of the Commission of the European Communities in relation to all ICBP's work for Neotropical parrot conservation.

\section{References}

Forshaw, J. M. and Cooper, W. T. (1989) Parrots of the world. Third (revised) edition. Poole: Blandford.

Juniper, T. and Yamashita, C. (1990) The conservation of Spix's Macaw. Oryx 24: 224-228.

Meyer de Schauensee, R. (1971) A guide to the birds of South America. Philadelphia: Academy of Natural Sciences.

Naumburg, E. M. B. (1928) Remarks on Kaempfer's collections in eastern Brazil. Auk 45: $60-65$.

Pinto, O. M. O. (1938) Catálogo de aves do Brasil. São Paulo: Secretária da Agricultura.

Ridgely, R. S. (1981) The current distribution and status of mainland neotropical parrots. 
Pp. $233-384$ in R. F. Pasquier, ed. Conservation of New World parrots. Washington, D.C.: Smithsonian Institution Press for the International Council for Bird Preservation (Techn. Publ. 1).

Roth, P. (1990) Spix-Ara Cyanopsitta spixii: Bericht über ein 1985-1988 durchgeführtes Projekt. Papageien 3: 86-88; 4: 121-125.

Sick, H. (1985) Ornitologia brasileira, uma introdução. Brasília: Editora Universidade de Brasilia.

Silva, T. (1989) A monograph of endangered parrots. Pickering, Ontario: Silvio Mattacchione and $\mathrm{Co}_{\mathrm{O}}$.

Thomsen, J. B. and Munn, C. A. (1988) Cyanopsitta spixii: a non-recovery report. Parrotletter $1: 6-7$.

A. T. JUNIPER

International Council for Bird Preservation, 32 Cambridge Road, Girton, Cambridge $\mathrm{CB}_{3} \mathrm{OPJ}$, U.K.

C. YAMASHITA

Rua Voluntários da Patria 4130/52A 02402 São Paulo SP, Brazil. 